\title{
CORRIGENDUM
}

\section{War and security at sea: Warning shots - CORRIGENDUM}

\section{Vincent Bernard, Editor-in-Chief}

doi:10.1017/S1816383117000443. First published online by Cambridge University Press, 2 October 2017.

The text of the above editorial by Vincent Bernard referred to "the Falklands War". This should have instead read "Falklands/Malvinas war", with the disclaimer that the designation as such does not imply official endorsement, nor the expression of any opinion whatsoever concerning the legal status of any territory, or concerning the delimitation of its frontiers or boundaries."

\section{Reference}

Vincent Bernard, 'War and security at sea: Warning shots' in International Review of the Red Cross, 2017, doi: 10.1017/S1816383117000443. 